\title{
The World Bank and Fragile States: Dynamics of Cooperation and Aid Structure ${ }^{1}$
}

\author{
A. Solomatin
}

Alexey Solomatin - PhD Candidate, School of World Politics, Lomonosov Moscow State University, 1-51 Leninskiye Gory, 119991 Moscow, Russian Federation; E-mail: alesolomatin@gmail.com

\begin{abstract}
The eradication of extreme poverty in fragile states is one of the central problems of global governance at the present time. Development of these states is hindered by instability, weak public and social institutions or ongoing conflicts and violence. The World Bank is a key partner of fragile states, which account for almost a third of the world's population.

This article is a continuation of research exploring the evolution of conceptual and practical approaches by the World Bank to cooperation with fragile states. Its methodology is based on a multilevel analysis of the securitization of foreign aid as proposed by J. Lind and J. Howell of the London School of Economics. The main focus of this examination is on the dynamics of the change of scale and structure of the World Bank's aid to fragile states in comparison with global armed trends of providing aid to fragile states as well.

This article concludes that statements about the priority of the Bank's work in fragile states have not yet been realized in practice. The Bank remains committed to the standard approach to working with this group of recipients, which involves serious risks. The World Bank leans toward supporting projects in fragile states which increases volatility and reduces aid predictability. This trend undermines the development potentials of recipient states.

Attention is drawn to political factors influencing aid flows to fragile states and particularly to the tendency of increasing the share of aid provided to fragile states through multi donor trust funds rather than through the mechanisms of the International Development Association (IDA). This trend indicates that the Bank is no longer a central point of aid distribution to the recipients, pointing to the lack of trust of donor states in the existing mechanisms and rules of aid distribution. It also reveals the expanding role of donors' strategic interests in the process of choosing recipients of World Bank aid.
\end{abstract}

Key words: World Bank; fragile states; official development assistance; standard approach; project support; multi donor trust fund; "bilateralization" of multilateral aid

For citation: Solomatin A. (2018) The World Bank and Fragile States: Dynamics of Cooperation and Aid Structure. International Organisations Research Journal, vol. 13, no 1, pp. 114-132. (In Russian and English.) DOI: 10.17323/1996-7845-2018-01-07

At present, one of the key challenges of global governance is to achieve a qualitative breakthrough in ending extreme poverty in regions where development is hindered by the volatility of governmental and public institutions or ongoing conflicts and armed violence - regions that are home to nearly two billion people who make up close to

\footnotetext{
${ }^{1}$ The editorial board received the article in October 2017.

This research is supported by a grant from the Russian Science Foundation (project no. 15-18-30066).
} 
one-third of the world's population. ${ }^{2}$ According to Organisation for Economic Cooperation and Development (OECD) forecasts, by 2030 over $60 \%$ of the world's poor will be living in such problem areas. ${ }^{3}$ Because none of the low-income "fragile states" managed to achieve the Millennium Development Goals (MDGs) set out in the Millennium Declaration in 2000, peace, safety and strong institutions were collectively included as an additional sustainable development goal (SDG 16) in the 2030 Agenda for Sustainable Development [Bartenev, 2015]. This clearly indicates that the international community is paying increased attention to enhancing states' resilience to internal and external risks in accordance with the conceptual paradigm of the security - development nexus established in the 2000s [Stern, Öjendal, 2010; Yudin, 2016].

A major role in helping fragile states is played by multilateral organizations. According to the OECD, approximately $50 \%$ of all aid for this group of recipients is provided through such organizations, compared to $37 \%$ in other developing countries. Moreover, the more fragile the state, the larger share of aid it receives from multilateral organizations. $^{4}$

The World Bank acts as the key partner of fragile states. The issues of post-conflict recovery, overcoming fragility and providing official development assistance (ODA) are governed by the International Bank for Reconstruction and Development (IBRD) and International Development Association (IDA), which together make up the World Bank in the strictest sense. The need for effective efforts across an entire range of focus areas in fragile states poses a significant challenge for the World Bank, which has set itself the ambitious goal of ending global poverty by 2030 and promoting shared prosperity in compliance with the principles of sustainable development. ${ }^{5}$

Despite the indisputable importance and relevance of the topic under consideration, it has not yet been adequately explored in the scientific literature. National studies on the allocation, targeting and volume of aid flows from multilateral organizations are extremely rare [Zaytsev, 2011a; Bardin, 2015]. As for foreign researchers, they have mainly focused on the allocation of foreign aid from donor countries for many years [McKinley, Little, 1979; Alesina, Dollar, 2000]. Studies specifically exploring multilateral aid only gained momentum in the first decade of the 21st century. Of particular interest is the work by Eric Neumayer, Professor of Environment and Development at the London School of Economics, which examines the determinants of aid allocation by regional development banks and United Nations agencies [Neumayer, 2003]. He observes that many multilateral donors tend to aid less-populated states and discovers a very weak correlation between the amount of aid provided and the level of political

${ }^{2}$ World Bank Fragility, Conflict and Violence Overview. Available at: http://www.worldbank.org/en/ topic/fragilityconflictviolence/overview (accessed 3 July 2017).

${ }^{3}$ OECD (2016) States of Fragility: Highlights. Available at: http://www.oecd.org/dac/conflict-fragilityresilience/docs/Fragile-States-highlights-2016.pdf (accessed 5 July 2017).

${ }^{4}$ OECD (2014) Fragile States: Domestic Revenue Mobilisation in Fragile States. Available at: http:// reliefweb.int/sites/reliefweb.int/files/resources/FSR_2014.pdf (accessed 23 July 2017).

${ }^{5}$ World Bank Group Strategy. Available at: http://sistemas.mre.gov.br/kitweb/datafiles/IRBr/pt-br/ file/CAD/LXVI\%20CAD/Bibliografia/Coopera\%C3\%A7\%C3\%A3o\%20Financeira/WB\%20Strategy\%202. pdf (accessed 03 August 2017). 
freedoms in the recipient country. The question of motives behind the allocation of development assistance by international organizations is raised by Professor Andrew Rosser of the University of Melbourne in his work on the approach of the Asian Development Bank (ADB) toward fragile states [Rosser, 2009]. In particular, he argues that the ADB regards work in these countries not as an attempt to improve their development effectiveness, but rather as a project aimed at achieving certain political objectives. Moreover, according to Rosser, the ADB applies the securitization approach to development assistance.

The only relevant study specifically focused on the World Bank is coauthored by Professor Thomas E. Flores of George Mason University and Professor Irfan Nooruddin of Ohio State University. They evaluate the effectiveness of World Bank programmes in fragile states and observe no evidence of a systematic effect on the successful economic recovery of the partner countries [Flores, Nooruddin, 2009].

The present article goes a step further by studying these countries in more detail and highlighting the features and trends of the World Bank's interaction with fragile states, treating these as a distinct and very specific category of aid recipient. The purpose of this paper is to identify the features and characteristics of World Bank aid flows to fragile states and to detect the main trends in its provision.

This article continues a series of studies exploring the evolution of the World Bank's conceptual and practical approaches to engagement with fragile states [Solomatin, 2016] and further develops the method of multilevel analysis proposed by London School of Economics professors Jeremy Lind and Jude Howell to examine the securitization of international aid. According to Lind and Howell, "the securitization of aid and development" is the "absorption of global and national security interests into the framing, justification, design, and implementation of aid and development policies" which manifests itself at three different levels: in official statements and doctrinal documents (the macro level); in changes in institutional arrangements, the volume and direction of aid flows (the meso level); and in the planning and implementation of specific programmes and projects (the micro level) [Howell, Lind, 2009]. This article, therefore, continues research at the meso level in that it focuses on studying the dynamics of change in the volume and allocation of World Bank aid to fragile states. The article will consider aid flows to fragile states starting in 2006, when the Bank began to publish the list of countries included in this category.

The World Bank Group (WBG) ${ }^{6}$ is one of the largest international institutions providing financial and technical assistance to developing countries.

${ }^{6}$ The World Bank Group comprises five constituent institutions: the International Bank for Reconstruction and Development (IBRD), the International Development Association (IDA), the International Finance Corporation (IFC), the Multilateral Investment Guarantee Agency (MIGA) and the International Centre for Settlement of Investment Disputes (ICSID). 
Since the 1970s, the WBG has employed the performance-based allocation (PBA) system for its aid. The main purpose of this method is to reward states that demonstrate good performance indicators with a greater volume of aid. The method is based on the Country Policy and Institutional Assessment (CPIA) rating which assesses the estimated quality of state policies in a given country - its commitment to poverty reduction, sustainable development and effective use of aid. The rating is calculated on the basis of the expert assessment of 16 criteria grouped into four clusters:

1. Economic Management

1.1. Monetary and Exchange Rate Policies

1.2. Fiscal Policy

1.3. Debt Policy and Management

2. Structural Policies

2.1. Trade

2.2. Financial Sector

2.3. Business Regulatory Environment

3. Policies for Social Inclusion/Equity

3.1. Gender Equality

3.2. Equity of Public Resource Use

3.3. Building Human Resources

3.4. Social Protection and Labour

3.5. Policies and Institutions for Environmental Sustainability

4. Public Sector Management and Institutions

4.1. Property Rights and Rule-based Governance

4.2. Quality of Budgetary and Financial Management

4.3. Efficiency of Revenue Mobilization

4.4. Quality of Public Administration

4.5. Transparency, Accountability and Corruption in the Public Sector

The performance calculation formula has changed over time: until 1994, it relied exclusively on the CPIA; then, until 2008, it combined the overall CPIA score and the WBG project portfolio performance of the country. Since 2009, CPIA has been broken down into two parts. The first covers three clusters measuring the quality criteria for economic, structural and social policies; the second covers the quality of public sector management and the development of public institutions. The second part played a key role in determining the CPIA score - the cornerstone of the PBA system. In 1997, an increasingly popular study was published by Craig Burnside and David Dollar, both employees of the World Bank. They found that aid was more effective in countries with better governance, providing the first econometric evidence supporting the effectiveness of PBA [Burnside, Dollar, 1997].

However, the PBA system did not suit the needs of fragile and conflict-affected states. Rather, its absolute priority was the result of the so-called standard approach to "problem" recipients widely applied by the donor community until the mid-2000s. Aiding such recipients was associated with a higher probability of programme failure due to the deterioration of political situations and the risk of doing harm, threats to the lives of 
the implementers and a strong probability of the misallocation of funds due to endemic corruption. The standard approach involved providing less aid to such countries as compared to other recipients, the use of extreme caution when allocating funds through direct budget support and an orientation toward project financing ${ }^{7}$ [Bartenev, 2012].

The fact that these "problem" recipients were lagging behind in achieving the MDGs and were perceived as sources of transnational threats after the 9/11 attacks prompted a revision of the standard approach. To that end, the management of the World Bank established a special Implementation Trust Fund for Low-Income Countries Under Stress (LICUS), ${ }^{8}$ and introduced special procedures for engaging with these partners which resulted in a blurring of the original concept of PBA [Guillaumont, Guillaumont, Wagner, 2010]. Still, while the formula for calculating performance indicators for PBA was more or less clear and transparent, the special procedures for engaging with the countries in this category were not. Critics of the PBA system also pointed out that the CPIA rating which served as the basis for PBA only defined the quality of state governance and failed to take into account the lack of human capital and the economic vulnerability of certain recipients [McGillivray, Cuong, 2017; Kanbur, 2005].

In 2006, the World Bank began to compile its own list of fragile states based on the criteria it developed. ${ }^{9}$ During 2006-2009 such recipients were referred to as LICUS, in 2010 as fragile states and from 2011-2015, as the constituents of the Harmonized List of Fragile Situations (see Appendix 1).

Today the role of PBA in allocating aid from the World Bank is diminishing due to the increasingly popular practice of establishing various multi donor trust funds (MDTFs) set up by one or more donor countries. Procedures for allocating money through these funds are often specific to a certain mechanism and are opaque. Moreover, good governance is no longer used as the central criterion for the allocation of funds to a state. German researcher Vera Eichenauer and WBG employee Stephen Knack argue that the aid provided by single donor World Bank trust funds shows much greater selectivity and compliance with the strategic interests of the donor [Eichenauer, Knack, 2016]. Thus, as per the calculations of French scientist Laurent Wagner, from 2009-2013 World Bank trust funds focused specifically on aiding low-income countries and fragile states despite their low CPIA scores [Wagner, 2014]. This trend makes World Bank aid allocation among the recipients more discrete and dependent on the strategic interests of the donor financing a certain trust fund. In this context, the notion of "bilateralizing multilateral aid" [Eichenauer, Knack, 2015] emerged to refer to the gradual shift in control over the allocation of aid from the multilateral organizations to the donor countries financing the trust funds, guided primarily by their own interests.

${ }^{7}$ Project financing is the implementation of individual IDA projects. A project is a set of inputs, activities and outputs which are agreed upon with the partner country for the purpose of reaching specific objectives/ outcomes within a defined time frame, with a defined budget and impacting a defined geographical area.

${ }^{8}$ Low-Income Countries Under Stress Implementation Trust Fund (2003) World Bank Operations Policy and Country Services. Available at: http://siteresources.worldbank.org/INTLICUS/Resources/ LICUSimplmementation.pdf (accessed 05 August 2017).

${ }^{9}$ The statistical data in this article were considered in accordance with the relevant annual lists of fragile states. 
The volume of annual contributions from the IBRD/IDA trust funds demonstrated steady growth from $\$ 1.87$ billion in 2006 to $\$ 4.3$ billion $^{10}$ in the fiscal year for $2012,{ }^{11}$ whereas the growth rates of contributions by the IDA as a whole over the same period are not as impressive: from $\$ 8.9$ billion to $\$ 11$ billion. ${ }^{12}$

In general, the overall volume of World Bank aid to fragile states began to grow after 2006. By the end of the first decade of the 21st century, it reached $\$ 3.8$ billion and nearly $\$ 4.3$ billion in 2012 after the Arab Awakening. In 2015, the volume of aid to fragile states decreased significantly to almost $\$ 2.5$ billion, which is about $18 \%$ of the total ODA provided by the World Bank that year. Researchers have also noted the high volatility of aid flows to fragile states [McGillivray, 2005]; it is confirmed by simply observing the changes in the volume of aid provided to this group of recipients in the period from 2006 to 2015 (see Figure 1).

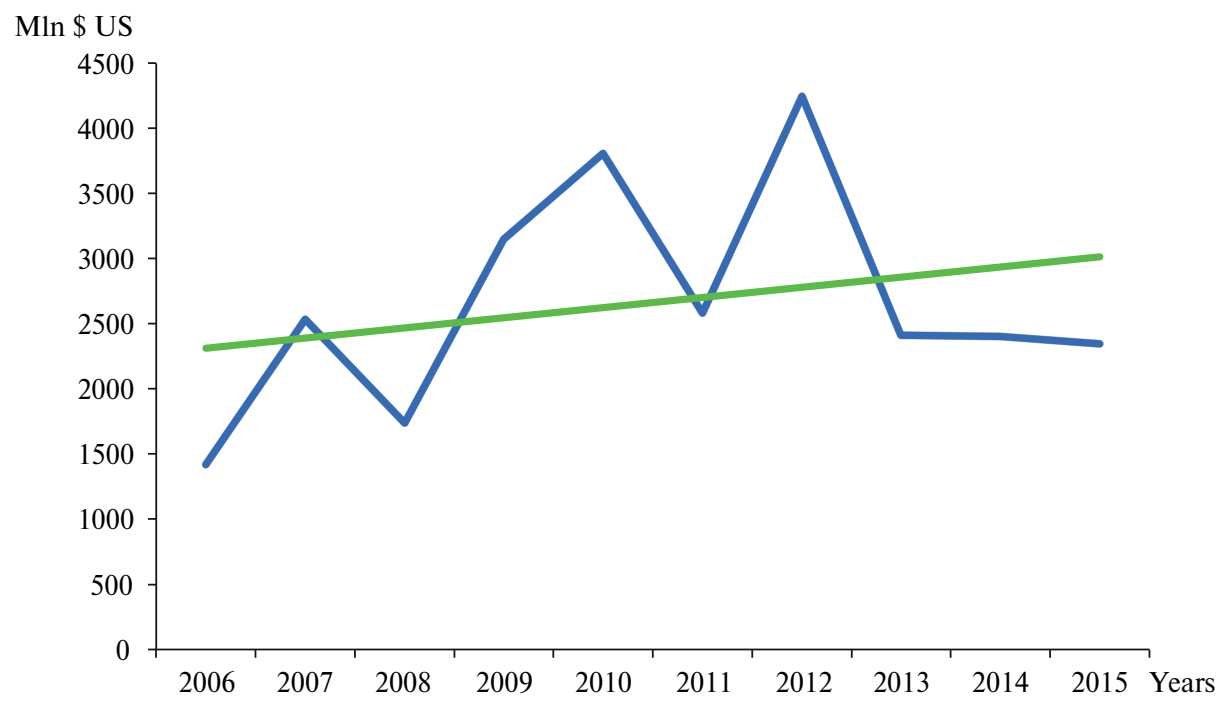

Figure 1. Volume of Aid to Fragile States from the World Bank (2006-2015, in \$ Millions)

Source: Data from stats.oecd.org

In this regard, the World Bank follows global trends: at the 2005 G8 summit, the leaders committed to intensify their support of developing countries and to cancel the debts of the 18 poorest countries; after this, a marked increase is observed in World Bank aid to fragile states. Maximum volume during the period analyzed was achieved in 2012, a year after the Monrovia Roadmap ${ }^{13}$ was signed with the aim of preventing

\footnotetext{
${ }^{10}$ World Bank Group Finances. IBRD/IDA/IFC Trust Funds - Annual Cash Contributions and Disbursements. Available at: https://finances.worldbank.org/Trust-Funds-and-FIFs/IBRD-IDA-IFC-TrustFunds-Annual-Cash-Contributions/iww5-3sst (accessed 08 August 2017).

${ }^{11}$ The fiscal year of the World Bank runs from 1 July through 30 June. There are no publicly available official data on the volume of contributions of the IDA and IBRD trust funds after 2012.

${ }^{12}$ World Bank Group Finances. Available at: https://finances.worldbank.org (accessed 12 August 2017).

${ }^{13}$ The Monrovia Roadmap on Peacebuilding and Statebuilding. Available at: http://www.icnl.org/ research/library/files/Transnational/monrovia.pdf (accessed 3 November 2017).
} 
conflicts and achieving the MDGs in situations of fragility, and also after the adoption of the New Deal for Engagement in Fragile States. ${ }^{14}$ Naturally, these developments stimulated the activity of the World Bank in the countries under consideration, which was reflected in the volume of aid provided by the Bank to fragile states.

In terms of the ratio of the total volume of ODA provided by the World Bank on a global scale to the volume of aid to fragile states, the overall trends of both indicators are similar. The only outstanding spike was observed in 2006 when total ODA from the World Bank rapidly increased more than fourfold (from $\$ 8.9$ billion in 2005 to $\$ 40.3$ billion in 2006) before returning to the previously established trend a year later. This spike was due to the fact that in 2005, in addition to the World Bank and IMF Initiative for Heavily Indebted Poor Countries (HIPC), the Multilateral Debt Relief Initiative (MDRI) was adopted. Under its terms, three multilateral organizations - the IMF, the World Bank and the African Development Bank - fully canceled their debt claims on the countries participating in the Initiative. ${ }^{15}$ The countries needed to meet a number of conditions in order to be able to participate in the MDRI. So, if the deviation of the 2006 indicator is excluded, the trend lines reflecting changes in the overall volume of ODA provided by the World Bank and the volume of ODA it provided to fragile states exhibit a similar evolution (see Figure 2).

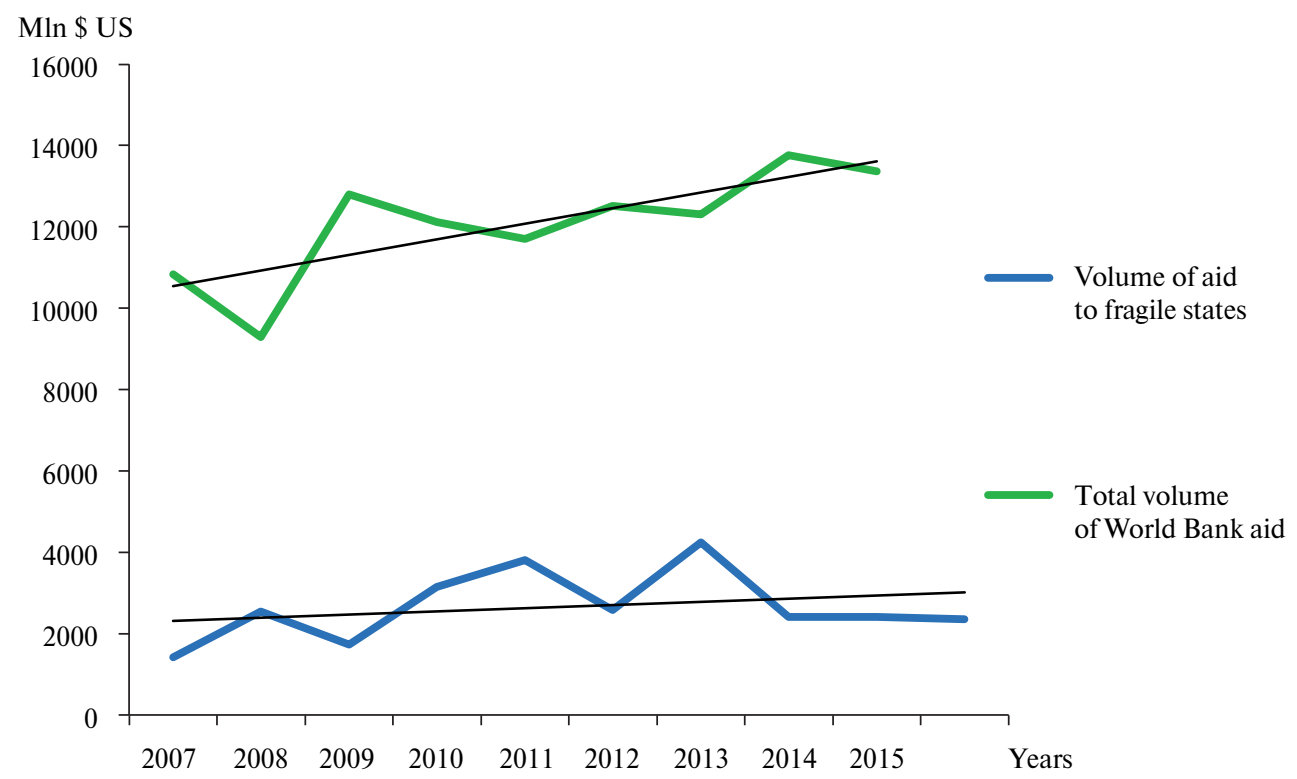

Figure 2. Volume of Aid Provided by the World Bank to Fragile States and Globally (2007-2015, in \$ Millions)

Source: Data from stats.oecd.org

${ }^{14}$ A New Deal for Engagement in Fragile States (2011) Available at: https://www.pbsbdialogue.org/media/ filer_public/07/69/07692de0-3557-494e-918e-18df00e9ef73/the_new_deal.pdf (accessed 12 October 2017).

${ }^{15}$ IMF. The Multilateral Debt Relief Initiative Factsheet. Available at: http://www.imf.org/external/np/ exr/facts/mdri.htm (accessed 12 August 2017). 
This similarity seems counterintuitive, as the World Bank's representatives have repeatedly asserted the priority of projects in fragile states. The analysis of changes in the share of aid provided to fragile states within the total amount of aid from the World Bank also suggests that there is no steady trend of increasing funding for projects in these countries. On the contrary, it has undergone a considerable decline in recent years (see Table 1), which is certainly cause for concern.

Table 1. The Share of Aid to Fragile States in the Total Volume of Aid Provided by the World Bank (2006-2015, \%)

\begin{tabular}{|c|c|c|c|c|c|c|c|c|c|}
\hline $2006, \%$ & $2007, \%$ & $2008, \%$ & $2009, \%$ & $2010, \%$ & $2011, \%$ & $2012, \%$ & $2013, \%$ & $2014, \%$ & $2015, \%$ \\
\hline 3.5 & 23.4 & 18.7 & 24.6 & 31.4 & 22.0 & 33.9 & 19.6 & 17.5 & 17.5 \\
\hline
\end{tabular}

Source: Data from stats.oecd.org

The indicators of the volume of aid to these countries suggest that the World Bank is still guided by the principle - described, among others, by Magüi Moreno Torres and Michael Anderson in 2014 - that sees fragile states as difficult environments for effective aid implementation and views their governments as unable or unwilling to harness domestic and international resources effectively for poverty reduction [Torres, Anderson, 2004]. Therefore, projects there are not receiving significantly increased funding, which shows the reluctance of the World Bank to intensify its engagement in the priority recipient countries despite statements to the contrary.

The premise that the effectiveness of the World Bank's engagement in fragile states leaves much to be desired is confirmed by Brookings Institution experts Laurence Chandy, Brina Seidel and Christine Zhang, who claim that the WBG's engagement in fragile environments is markedly less effective than in stable states [Chandy, Seidel, Zhang, 2016]. Moreover, the World Bank has been unable to fully abandon the so-called standard approach toward aiding fragile states and selecting the forms of development assistance: the share of project financing in World Bank aid to fragile states remained consistently high from 2006 to 2015 , reaching $80 \%$ and even $90 \%$ in some years (see Figure 3).

The advantages of project financing which apparently led the World Bank to largely favour this form of assistance are as follows: reduced fiduciary risks ${ }^{16}$ through stricter control over the allocation of funds, the visibility of branded projects and the opportunity of rapid career advancement for individual employees if the project is successful [Williamson, Kizilbash Agha, et al., 2008]. Certainly, these advantages are significant in the context of fragile states where the number of risks faced by the donors is great and the value of overcoming them is immense. Nevertheless, the issue of rethinking the standard approach remains open.

${ }^{16}$ Fiduciary risk is the risk of loss arising from the failure of the institution to ensure the safety of its own assets or the profitability of the property entrusted to it by another party. 


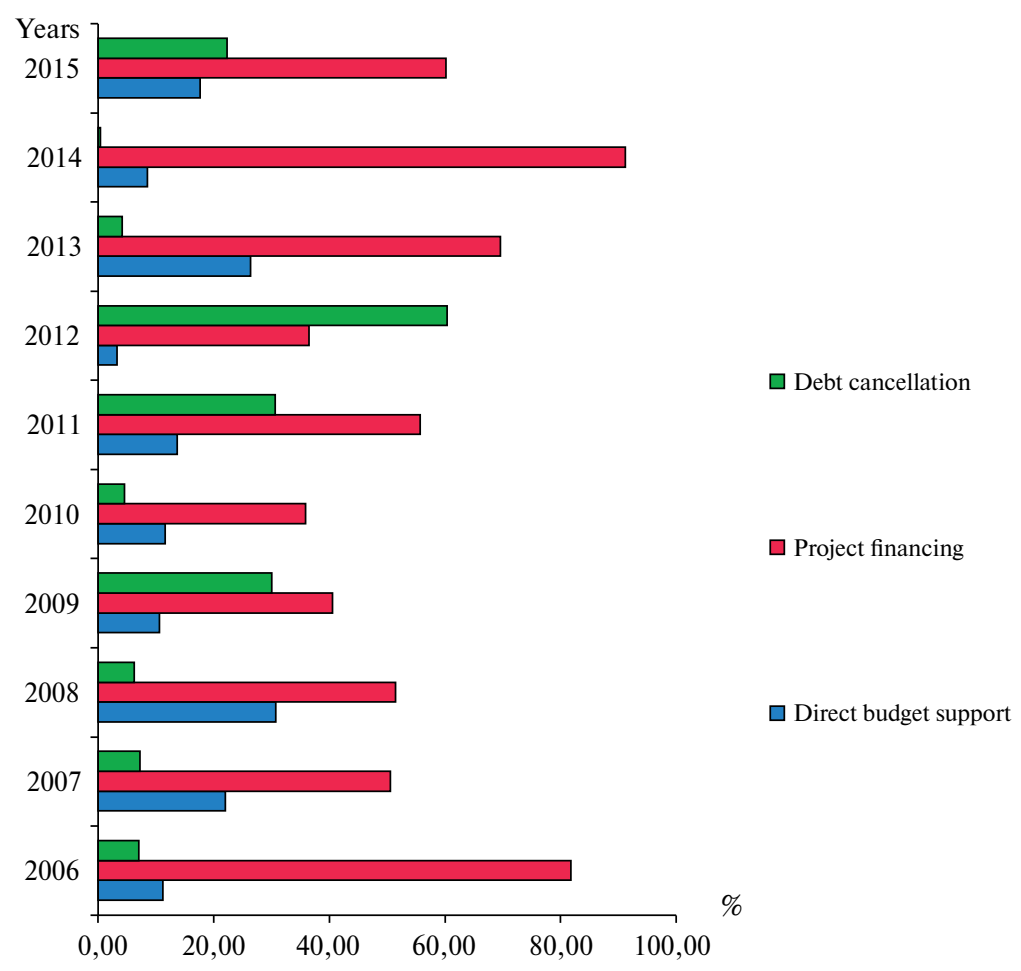

Figure 3. ODA Provided by the World Bank to Fragile States by Form of Assistance (2006-2015, \%)

Source: Data from stats.oecd.org

In order to gain a more comprehensive understanding of the World Bank's engagement in fragile states it is also necessary to examine the allocation of its aid flows by sector. During the period studied the main focus in fragile states was on the social infrastructure and services sphere - a sphere crucial for ensuring progress in achieving the MDGs (see Appendix 2). It includes efforts to develop human resources and improve living conditions in the recipient countries. It also covers such areas as education, healthcare, and population programmes, support for the public sector and civil society institutions and provision of clean water and sanitation. Throughout the decade considered, the major share of funds for this sphere was earmarked to support the public sector and civil society institutions, the correct functioning of which are essential to ensure the stability of the state, as well as to satisfy the basic health and education needs of the population to strengthen the human potential of these countries. The indicators here remained consistently high as compared to other sectors: between $\$ 668$ million and $\$ 1.1$ billion per year.

The social sphere was followed in the portfolio of the World Bank by the economic infrastructure and services sector which includes assisting the structures and services that stimulate economic activity. It is divided into two large clusters: energy and transport and communications. 
Assistance to production sectors in different years represented from five to $17 \%$ of the total World Bank aid to fragile states. This category includes three major domains: agriculture, fisheries and forestry; trade and industry; and tourism. It is worth noting that during the period studied, agriculture, fisheries and forestry received significantly more resources than industry, trade and tourism. The first of these categories accounted for about half of the aid directed to industrial sectors. The reason is quite simple: in fragile states, industry and the service sector are much less developed than agriculture, which provides employment for a significant proportion of the population and plays a more substantial role in the structure of the gross domestic product (GDP). Therefore, encouraging the solution of problems in this sphere in particular is a top priority.

A particularity of fragile states as compared to global indicators is the cancellation and restructuring of great amounts of debt which these countries are incapable of repaying in certain years. It clearly distinguishes the structure of aid flows to fragile states from other categories of recipient countries. In some years (2009, 2010 and 2012) the amount of debt canceled and restructured in fact exceeded the amount of aid provided to social sectors (see Figure 4).

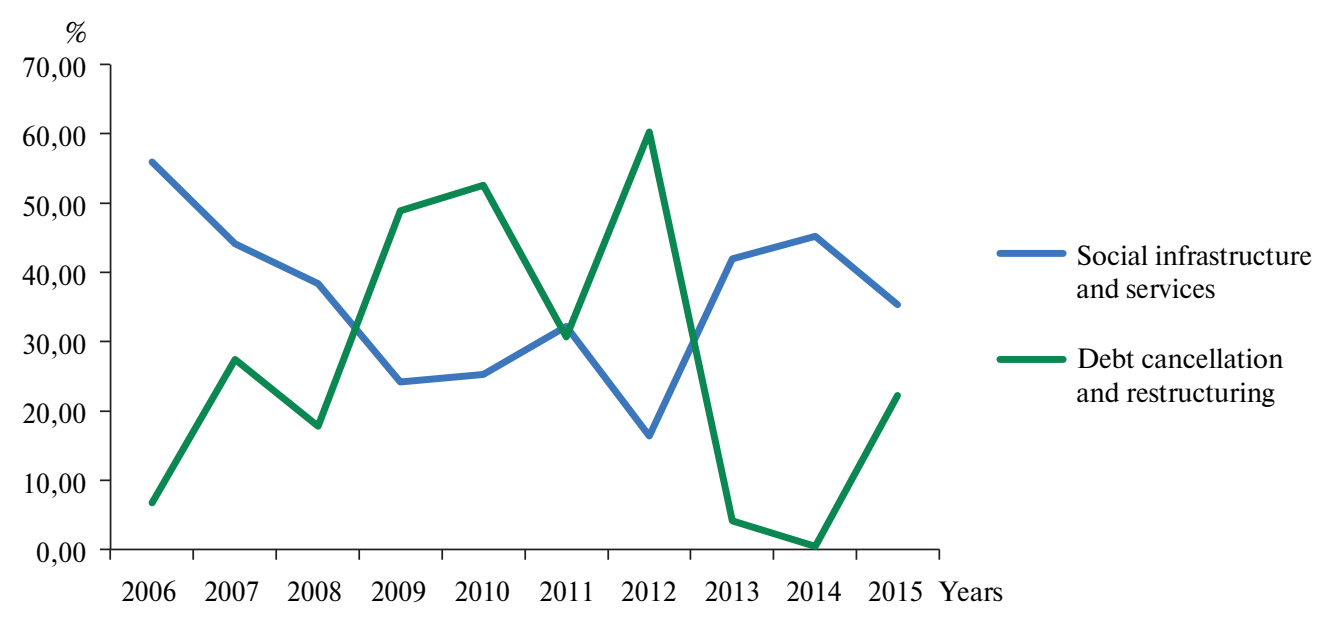

Figure 4. Shares of the Social Infrastructure and Services vs Debt Cancellation and Restructuring in World Bank Aid to Fragile States, 2006-2015

Source: Data from stats.oecd.org

There were certainly good reasons for this: primarily, after the launch of the abovementioned MDRI - in which many fragile states participated - the amount of debt restructuring and cancellation began to grow rapidly. By 2013, debt cancellation was completed for 35 of the 39 participating countries and the share of debt cancellation and restructuring in the total World Bank aid to fragile states dropped to almost nothing; as a result, the social sphere regained its leading position in the allocation of aid flows by sector. By 2015 aid flows into the social sphere almost equaled the volume of 
assistance for the economic sector - the lack of a well-functioning economic system able to ensure the proper functioning of the state and its institutions makes these "problem" states repeatedly turn to donors for financial aid. As a result, the volume of debt that fragile states are not able to clear increases each year which prompts international financial institutions to launch major programmes of assistance to countries that do not have the resources to manage their debt load.

The issue of fragile states today occupies an increasingly prominent place in the discourse of the World Bank; their significance is emphasized in the organization's doctrinal documents ${ }^{17}$ and the statements of its leaders. ${ }^{18}$ However, the theoretical aspects of the fragility issue have been developed within the organization much more rapidly than actual changes in the practices of engagement with this category of recipients. The declared prioritization of projects in fragile states has not yet been adequately confirmed in practice: while rejecting the standard approach in word, the World Bank has in fact continued to rely on it in a number of aspects.

Perhaps the most important manifestation of such "continuity" is the focus on project financing as opposed to programme-oriented approaches and direct budget support. On the one hand it seems rational, as with this form of assistance the donors minimize their risks; on the other hand, it can create new risks for the recipient. The implementation of individual projects does not necessarily strengthen state institutions; instead, it may undermine their ability to manage the development process. Various requirements regarding accounting and financial reporting can, in fact, increase the burden on government agencies in the recipient country.

Project financing increases aid volatility and reduces its predictability [Koeberle, Stavreski, 2006]. Greater aid predictability could help fragile states set the most appropriate direction for development and carry out strategic planning for the longer term. Enhancing the predictability of aid provided to these countries could be a significant contribution to the prevention of conflicts and fragility and improving the human development index (HDI). The current situation is such that fragile states are forced to constantly adjust their plans in accordance with new data on the volume of aid from the World Bank.

However, the high volatility and low predictability of aid provided to fragile states by the World Bank is also politically motivated. It comes down to the trend of increasing the share of aid provided to this category of recipients through multilateral trust funds of the World Bank as opposed to replenishing IDA funds, which would limit the World Bank's role in allocating aid flows among recipients. On the one hand,

${ }^{17}$ World Development Report 2011: Conflict, Security and Development. Available at: http:// siteresources.worldbank.org/INTWDRS/Resources/WDR2011_Full_Text.pdf (accessed 10 August 2017).

${ }^{18}$ Voice for the World's Poor: Selected Speeches and Writings of World Bank President James D. Wolfensohn, 1995-2005. vol. 889. 
it shows the donors' distrust of the existing mechanisms and rules for the allocation of funds; on the other, it speaks to the fact that the strategic interests of donor states are playing an increasingly important role in selecting aid recipients. In view of this, the discrepancy between the declaratory statements of the World Bank's leaders in the mid-2000s and the actual aid provided in the current decade may have a pragmatic explanation. Indeed, changes in conceptual approaches have always been introduced under favourable economic and financial conditions; whereas a large part of the 2010s has already been marked by budgetary constraints and the shift of the donor countries' focus towards combating the effects of the migration crisis within their own national borders. The confirmation of this hypothesis requires a more in-depth analysis of the financing structure of the multilateral World Bank trust funds, which could well form the subject of a separate study.

\section{References}

Alesina A., Dollar D. (2000) Who Gives Foreign Aid to Whom and Why? Journal of Economic Growth, no 5 (1), pp. 33-63.

Anderson M.B., Brown D., Jean I. (2012) Time to Listen: Hearing People on the Receiving end of International Aid. Cambrige, Massachusetts, CDA Collaborative Learning Projects, p. 184.

Bardin A.L. (2015) Rol' mezhdunarodnyh finansovyh institutov v global'nom politicheskom upravlenii (na primere Mezhdunarodnogo valjutnogo fonda i Vsemirnogo banka) [The Role of International Financial Institutions in Global Political Governance (Using the Example of International Monetary Fund and the World Bank)]. PhD Thesis, MGIMO-Universitet. (In Russian.)

Bartenev V.I. (2015) Vklyuchenie problem mira, bezopasnosti i kachestva upravleniya v global'nuyu povestku dnya ustoichivogo razvitiya na period do 2030 g.: analiz khoda i soderzhaniya mezhdunarodnykh peregovorov [Inclusion of Peace, Security, and Governance Targets in the Global Sustainable Development Agenda to 2030: Decomposing Intergovernmental Negotiations], vol. 10, no 3, pp. 7-32. (In Russian.)

Bartenev V.I. (2012) "Novyj kurs" okazanija pomoshhi "nestabil'nym gosudarstvam": istoki, komponenty, perspektivy [The New Deal of Providing Aid to Fragile States: Origins, Components, Perspectives]. Vestnik Moskovskogo universiteta. Ser. 25. Mezhdunarodnye otnoshenija i mirovaja politika, no 4, pp. 113-143. (In Russian.)

Burnside A., Dollar D. (1997) Aid, Policies, and Growth. Working Paper, no 1777. World Bank, Washington, DC.

Chandy L., Seidel B., Zhang C. (2016) Aid Effectiveness in Fragile States. How Bad is it and How Can it Improve? Global Economy and Development at Brookings, 16 December.

Chauvet L., Collier P. (2004) Development Effectiveness in Fragile States: Spillovers and Turnarounds. Centre for the Study of African Economies, Department of Economics, Oxford University: Oxford.

Collier P., Dollar D. (2002) Aid Allocation and Poverty Reduction. European Economic Review, no 46, pp. 1475-1500.

Collier P., Hoeffler A. (2002) Aid, Policy, and Growth in Post-Conflict Societies. Policy Research Working Paper, no 2902. World Bank, Washington, DC.

Eichenauer V.; Knack S. (2015) Bilateralizing Multilateral Aid? Aid Allocation by World Bank Trust Funds, Beiträge zur Jahrestagung des Vereins für Socialpolitik 2015: Ökonomische Entwicklung - Theorie und Politik - Session: Public Sector Economics and Developing Countries, no E14-V3. 
Eichenauer V., Knack S. (2016) Poverty and Policy Selectivity of World Bank Trust Funds. Policy Research working paper, no WPS 7731. Washington, D.C.: World Bank Group.

Flores T.E., Nooruddin I. (2009) Financing the Peace: Evaluating World Bank Post-Conflict Assistance Programs. The Review of International Organizations, vol. 4, iss. 1, pp. 1-27.

Guillaumont P., Guillaumont Jeanneney S., and Wagner L. (2010) How to Take into Account Vulnerability in Aid Allocation Criteria? ABCDE Conference Stockholm, Ferdi Working paper P13.

Howell J., Lind J. (2009) Changing Donor Policy and Practice in Civil Society in the Post-9/11 Aid Context. Third World Quarterly, vol. 30, no 7, pp. 1279-1296.

Judin N.V. (2016) Svjazka bezopasnost' - razvitie: problemy teoreticheskogo osmyslenija [Security-Development Nexus: problems of conceptualization]. Vestnik Moskovskogo universiteta. Ser. 25. Mezhdunarodnye otnoshenija i mirovaja politika, vol. 8, no 1, pp. 39-71. (In Russian.)

Kanbur R. (2005) Réformer la formule: unemodeste proposition pour inclure des critères de résultatsdans les procéduresd'allocation de l'aide de l'IDA. Paper for the 2nd AFD-EUDN.

KoeberleS., Stavreski Z. (2006) Budget Support: Concepts and Issues in Budget Support as More Effective Aid. Recent Experiences and Emerging Lessons. World Bank, Washington, DC.

McGillivray M. (2005) Aid Allocation and Fragile States. World Institute for Development Economics Research, UNU, paper presented at the Senior Level Forum on Development Effectiveness in Fragile States, OECD-DAC, 13-14 January, London.

McGillivrayM., Pham Thi Kim Cuong (2017) Reforming Performance-Based Aid Allocation Practice. World Development, vol. 90, iss. 2.

McKinley R.D., Little R. (1979) The US Aid Relationship: A Test of the Recipient Need and the Donor Interest Models. Political Studies Association, vol. 27, iss. 2, pp. 236-250.

Neumayer E. (2003) TheDeterminants of Aid Allocation by Regional Multilateral Development Banks and United Nations Agencies. London: LSE Research Online.

Rosser A. (2009) Risk Management, Neo-liberalism and Coercion: The Asian Development Bank's approach to 'fragile states'. Australian Journal of International Affairs, vol. 63, iss. 3, pp. 376-389.

Solomatin A.I. (2016) Jevoljucija podhodov Vsemirnogo banka k vzaimodejstviju s "nestabil'nymi gosudarstvami": osnovnyej etapy, determinanty i napravlenija [The Evolution Of World Bank's Engagement in Fragile States: Main Stages, Determinants and Directions]. Vestnik Moskovskogo universiteta. Ser. 25: Mezhdunarodnye otnoshenija i mirovaja politika, vol. 8, no 2, pp. 145-181. (In Russian.)

Stern M., Öjendal J. (2010) Mapping the Security-Development Nexus: Conflict, Complexity, Cacophony, Convergence? Security Dialogue, vol. 41, no 1, pp. 5-29. DOI: 10.1177/0967010609357041

Torres M.M., Anderson M. (2004) Fragile States: Defining Difficult Environments for Poverty Reduction. PRDE Working Papers 1. Poverty Reduction in Difficult Environments Team, Policy Division, DFID: London.

Wagner L. (2014) A Short Note on Earmarked Funds Geographic Allocation at the World Bank, Ferdi.

Williamson T., Kizilbash Z. Agha, with L. Bjornstad, G. Twijukye, Y. Mahwago and G. Kabelwa (2008) Building Blocks or Stumbling Blocks? The Effectiveness of New Approaches to Aid Delivery at the Sector Level. ABIA Project Working Paper 6.

Zajcev Ju.K. (2011) Mnogostoronnie mehanizmy upravlenija processami sodejstvija mezhdunarodnomu razvitiju [Multilateral Mechanisms of Managing International Development Assistance Processes]. Vestnik MGIMO Universiteta, no 5, pp. 67-76. (In Russian.) 


\section{Appendix 1. List of fragile states according to the World Bank classification (2006-2015)}

\begin{tabular}{|c|c|c|c|c|c|c|c|c|c|c|}
\hline & 2006 & 2007 & 2008 & 2009 & 2010 & 2011 & 2012 & 2013 & 2014 & 2015 \\
\hline \multicolumn{11}{|l|}{ Afghanistan } \\
\hline \multicolumn{11}{|l|}{ Angola } \\
\hline \multicolumn{11}{|l|}{$\begin{array}{l}\text { Bosnia and } \\
\text { Herzegovina }\end{array}$} \\
\hline \multicolumn{11}{|l|}{ Burundi } \\
\hline \multicolumn{11}{|l|}{ Cambodia } \\
\hline \multicolumn{11}{|l|}{ Cameroon } \\
\hline \multicolumn{11}{|l|}{$\begin{array}{l}\text { Central African } \\
\text { Republix }\end{array}$} \\
\hline \multicolumn{11}{|l|}{ Chad } \\
\hline \multicolumn{11}{|l|}{ Comoros } \\
\hline \multicolumn{11}{|l|}{ Côte d'Ivoire } \\
\hline \multicolumn{11}{|c|}{$\begin{array}{l}\text { Democratic Republic } \\
\text { of Congo }\end{array}$} \\
\hline \multicolumn{11}{|l|}{ Djibouti } \\
\hline \multicolumn{11}{|l|}{ Eritrea } \\
\hline \multicolumn{11}{|l|}{ Gambia, The } \\
\hline \multicolumn{11}{|l|}{ Georgia } \\
\hline \multicolumn{11}{|l|}{ Guinea } \\
\hline \multicolumn{11}{|l|}{ Guinea-Bissau } \\
\hline \multicolumn{11}{|l|}{ Haiti } \\
\hline \multicolumn{11}{|l|}{ Iraq } \\
\hline \multicolumn{11}{|l|}{ Kiribati } \\
\hline \multicolumn{11}{|l|}{ Kosovo } \\
\hline \multicolumn{11}{|l|}{ Lao PDR } \\
\hline \multicolumn{11}{|l|}{ Liberia } \\
\hline \multicolumn{11}{|l|}{ Libya } \\
\hline \multicolumn{11}{|l|}{ Madagascar } \\
\hline \multicolumn{11}{|l|}{ Malawi } \\
\hline Mali & & & & & & & & & & \\
\hline Marshall Islands & & & & & & & & & & \\
\hline Mauritania & & & & & & & & & & \\
\hline Micronesia & & & & & & & & & & \\
\hline Myanmar & & & & & & & & & & \\
\hline Nepal & & & & & & & & & & \\
\hline Nigeria & & & & & & & & & & \\
\hline Papua New Guinea & & & & & & & & & & \\
\hline
\end{tabular}




\begin{tabular}{|c|c|c|c|c|c|c|c|c|c|c|}
\hline & 2006 & 2007 & 2008 & 2009 & 2010 & 2011 & 2012 & 2013 & 2014 & 2015 \\
\hline \multicolumn{11}{|c|}{ Republic of the Congo } \\
\hline \multicolumn{11}{|c|}{ Sao Tome and Principe } \\
\hline \multicolumn{11}{|c|}{ Sierra Leone } \\
\hline \multicolumn{11}{|c|}{ Solomon Islands } \\
\hline \multicolumn{11}{|l|}{ Somali } \\
\hline \multicolumn{11}{|c|}{ South Sudan } \\
\hline \multicolumn{11}{|l|}{ Sudan } \\
\hline \multicolumn{11}{|l|}{ Syria } \\
\hline \multicolumn{11}{|l|}{ Tajikistan } \\
\hline \multicolumn{11}{|c|}{ Timor-Leste } \\
\hline \multicolumn{11}{|l|}{ Togo } \\
\hline \multicolumn{11}{|l|}{ Tonga } \\
\hline \multicolumn{11}{|l|}{ Tuvalu } \\
\hline \multicolumn{11}{|l|}{ Uzbekistan } \\
\hline \multicolumn{11}{|l|}{ Vanuatu } \\
\hline \multicolumn{11}{|c|}{ West Bank and Gaza } \\
\hline \multicolumn{11}{|c|}{ Western Sahara } \\
\hline \multicolumn{11}{|l|}{ Yemen } \\
\hline Zimbabwe & & & & & & & & & & \\
\hline
\end{tabular}

Source: World Bank Harmonized List of Fragile Situations. Режим доступа: http://www. worldbank.org/en/topic/fragilityconflictviolence/brief/harmonized-list-of-fragile-situations (Accessed: 07.08.17)

1. The boxes in gray mark years in which the country has a presence in the list of fragile states

2. Western Sahara is present in the World Bank's list in the period 2010-2012, but there's no data available about aid size to this country 


\section{Appendix 2. Allocation of the World Bank's aid flows to fragile states by sectors, 2006-2015}

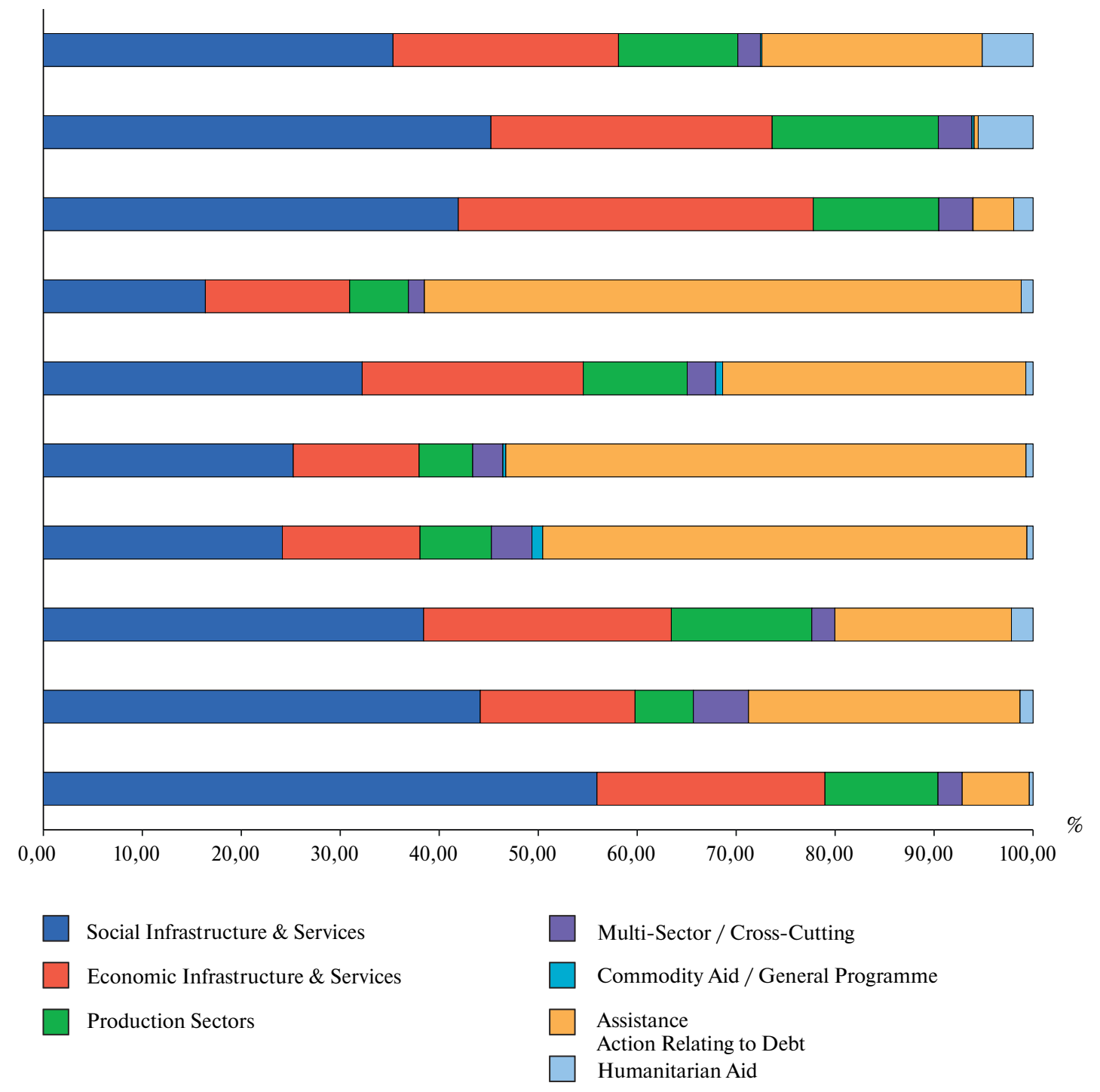

Source: stats.oecd.org. 


\title{
Всемирный банк и «нестабильные государства»: динамика взаимодействия и структура помощи ${ }^{1}$
}

\author{
А.И. Соломатин
}

Соломатин Алексей Игоревич - аспирант кафедры международных организаций и мировых политических процессов факультета мировой политики Московского государственного университета имени М.В. Ломоносова; Российская Федерация, 119991, Москва, ул. Ленинские горы, д. 1, стр. 51; E-mail: alesolomatin@ gmail.com

Одной из ключевых проблем глобального управления на современном этапе считается достижение качественного прорыва в области ликвидации крайней бедности в «нестабильных государствах», развитие которых затруднено из-за неустойчивости государственных и общественных институтов или продолжсающихся конфликтов и вооруженного насилия. Ключевым партнером этих стран, в которых проживает практически треть населения земного шара, выступает Всемирный банк.

Предлагаемая статья продолжает начатую ранее серию исследований эволюции концептуальных и практических подходов Всемирного банка к взаимодействию с «нестабильными государствами» и развивает метод «многоуровневого анализа» процесса «секьюритизации международной помощи», предложенный профессорами Лондонской школы экономики Дж.. Линдом и Дж. Хауэлл.

Основное внимание в статье сконцентрировано в первую очередь на изучении динамики изменения объемов и структуры распределения потоков помощи «нестабильным государствам» со стороны Всемирного банка. Осуществляется также и их сопоставление с общемировыми тенденциями в оказании помощи данной группе рециииентов.

Автор приходит к выводу, что на сегодняшний день заявления представителей Всемирного банка о приоритетности работы в «нестабильных государствах» так и не были в полной мере реализованы на практике. Организация фактически продолжсет придерживаться «стандартного подхода» в работе с «нестабильными государствами», предпочитая проектное финансирование, что увеличивает волатильность и снижсает предсказуемость помощи. Это, в свою очередь, создает дополнительные сложности для государств - получателей помощи.

В статье также отмечается влияние политических факторов на специфику оказания помощи «нестабильным государствам». Речь идет о тенденции к увеличению доли предоставляемой данной категории реципиентов помощи через многосторонние трастовые фонды Всемирного банка в противовес поддержске основного бюджета МАР, что ограничивает роль Банка в распределении потоков помощи между реципиентами. Это, с одной стороны, показывает недоверие государств-доноров к существующим механизмам и правилам распределения средств, с другой, говорит о том, что стратегические интересы доноров играют все большую роль в выборе государств - получателей помощи, оказываемой по каналам организации Всемирного банка.

Ключевые слова: Всемирный банк; «нестабильные государства»; официальная помощь развитию; «стандартный подход»; проектное финансирование; многосторонний трастовый фонд; «билатерализация многосторонней помощи»

Для цитирования: Соломатин А.И. Всемирный банк и «нестабильные государства»: динамика взаимодействия и структура помощи // Вестник международных организаций. 2018. Т. 13. № 1. С. 114-132. DOI:10.17323/1996-7845-2018-01-07

\footnotetext{
${ }^{1}$ Статья поступила в редакцию в октябре 2017 г.

Исследование выполнено за счет гранта Российского научного фонда (проект № 15-18-30066).
} 


\section{Источники}

Бардин А.Л. (2015) Роль международных финансовых институтов в глобальном политическом управлении (на примере Международного валютного фонда и Всемирного банка): дисс. ... канд. полит. наук. М.: МГИМО-Университет.

Бартенев В.И. (2012) «Новый курс» оказания помоши «нестабильным государствам»: истоки, компоненты, перспективы // Вестник Московского университета. Сер. 25. Международные отношения и мировая политика. № 4. С. 113-143.

Бартенев В.И. (2015) Включение проблем мира, безопасности и качества управления в глобальную повестку дня устойчивого развития на период до 2030 г.: анализ хода и содержания международных переговоров // Вестник международных организаций. № 3. С. 7-32.

Зайцев Ю.К. (2011) Многосторонние механизмы управления процессами содействия международному развитию // Вестник МГИМО Университета. № 5. С. 67-76.

Соломатин А.И. (2016) Эволюция подходов Всемирного банка к взаимодействию с «нестабильными государствами»: основные этапы, детерминанты и направления. Вестник Московского университета. Сер. 25: Международные отношения и мировая политика. Т. 8. № 2. С. 145-181.

Юдин Н. В. (2016) Связка безопасность - развитие: проблемы теоретического осмысления // Вестник Московского университета. Сер. 25. Международные отношения и мировая политика. T. 8. № 1. C. 39-71.

Alesina A., Dollar D. (2000) Who Gives Foreign Aid to Whom and Why? // Journal of Economic Growth. No. 5 (1). P. 33-63.

Anderson M.B., Brown D., Jean I. (2012) Time to Listen: Hearing People on the Receiving end of International Aid. Cambrige, Massachusetts, CDA Collaborative Learning Projects. P. 184.

Burnside A., Dollar D. (1997) Aid, Policies, and Growth. Working Paper. No. 1777. World Bank, Washington, DC.

Chandy L., Seidel B., Zhang C. (2016) Aid Effectiveness in Fragile States. How Bad is it and How Can it Improve? Global Economy and Development at Brookings. 16 December.

Chauvet L., Collier P. (2004) Development Effectiveness in Fragile States: Spillovers and Turnarounds. Centre for the Study of African Economies, Department of Economics, Oxford University: Oxford.

Collier P., Dollar D. (2002) Aid Allocation and Poverty Reduction. European Economic Review. No. 46. P. $1475-1500$.

Collier P., Hoeffler A. (2002) Aid, Policy, and Growth in Post-Conflict Societies. Policy Research Working Paper. No. 2902. World Bank, Washington, DC.

Eichenauer V., Knack S. (2015) Bilateralizing Multilateral Aid? Aid Allocation by World Bank Trust Funds, Beiträge zur Jahrestagung des Vereins für Socialpolitik 2015: Ökonomische Entwicklung - Theorie und Politik - Session: Public Sector Economics and Developing Countries. No. E14-V3.

Eichenauer V., Knack S. (2016) Poverty and Policy Selectivity of World Bank Trust Funds. Policy Research working paper. No. WPS 7731. Washington, D.C.: World Bank Group.

Flores T.E., Nooruddin I. (2009) Financing the Peace: Evaluating World Bank Post-Conflict Assistance Programs // The Review of International Organizations. Vol. 4. Iss. 1. P. 1-27.

Guillaumont P., Guillaumont Jeanneney S., Wagner L. (2010) How to Take into Account Vulnerability in Aid Allocation Criteria? ABCDE Conference Stockholm, Ferdi Working paper P13.

Howell J., Lind J. (2009). Changing Donor Policy and Practice in Civil Society in the Post-9/11 Aid Context // Third World Quarterly. Vol. 30. No. 7. P. 1279-1296.

Kanbur R. (2005) Réformer la formule: une modeste proposition pour inclure des critères de résultats dans les procédures d'allocation de l'aide de l'IDA. Paper for the 2nd AFD-EUDN. 
Koeberle S., Stavreski Z. (2006) Budget Support: Concepts and Issues in Budget Support as More Effective Aid. Recent Experiences and Emerging Lessons. World Bank, Washington, DC.

McGillivray M. (2005) Aid Allocation and Fragile States. World Institute for Development Economics Research, UNU, paper presented at the Senior Level Forum on Development Effectiveness in Fragile States, OECD-DAC, 13-14 January, London.

McGillivray M., Pham Thi Kim Cuong (2017) Reforming Performance-Based Aid Allocation Practice // World Development. Vol. 90. Iss. 2.

McKinley R.D., Little R. (1979) The US Aid Relationship: A Test of the Recipient Need and the Donor Interest Models // Political Studies Association. Vol. 27. Iss. 2. P. 236-250.

Neumayer E. (2003) The Determinants of Aid Allocation by Regional Multilateral Development Banks and United Nations Agencies. L.: LSE Research Online.

Rosser A. (2009) Risk Management, Neo-liberalism and Coercion: the Asian Development Bank's Approach to "Fragile States" // Australian Journal of International Affairs. Vol. 63. Iss. 3. P. 376-389.

Stern M., Öjendal J. (2010) Mapping the Security-Development Nexus: Conflict, Complexity, Cacophony, Convergence? // Security Dialogue. Vol. 41. No. 1. P. 5-29. DOI: 10.1177/0967010609357041

Torres M.M., Anderson M. (2004) Fragile States: Defining Difficult Environments for Poverty Reduction, PRDE Working Papers 1, Poverty Reduction in Difficult Environments Team, Policy Division, DFID: London.

Wagner L. (2014) A Short Note on Earmarked Funds Geographic Allocation at the World Bank. Ferdi.

Williamson T., Kizilbash Z. Agha, with L. Bjornstad, G. Twijukye, Y. Mahwago, G. Kabelwa (2008) Building Blocks or Stumbling Blocks? The Effectiveness of New Approaches to Aid Delivery at the Sector Level, ABIA Project Working Paper 6. 
